\title{
Genetic polymorphisms of the 5' untranslated regions of the HSP70 gene in Indonesian cattle populations
}

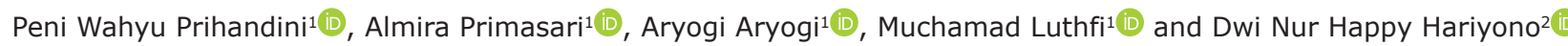 \\ 1. Beef Cattle Research Institute of Grati, Pasuruan 67183, Indonesia; 2. Department of Animal Science, Faculty of \\ Agriculture, Universitas Khairun, Ternate 97719, Indonesia. \\ Corresponding author: Peni Wahyu Prihandini, e-mail: peniprihandini@pertanian.go.id \\ Co-authors: AP: almira@pertanian.go.id, AA: aryogi@pertanian.go.id, ML: muchamadluthfi@pertanian.go.id, \\ DNHH: d.nur.happy@unkhair.ac.id \\ Received: 03-09-2021, Accepted: 29-12-2021, Published online: 27-01-2022
}

doi: www.doi.org/10.14202/vetworld.2022.168-172 How to cite this article: Prihandini PW, Primasari A, Aryogi A, Luthfi M, Hariyono DNH (2022) Genetic polymorphisms of the 5' untranslated regions of the HSP7O gene in Indonesian cattle populations, Veterinary World, 15(1): 168-172.

\begin{abstract}
Background and Aim: Heat shock proteins (HSPs) are a group of proteins that play a significant role in protecting cells against cellular stress. HSP70 is a conserved, sensitive, and abundant gene associated with heat stress's physiological adaptability. The objective of this study was to reveal the polymorphisms of the partial sequences of the HSP70 gene ( 5 ' untranslated region [UTR]) in seven cattle populations in Indonesia.

Materials and Methods: Polymerase chain reaction products (551 bp) of the HSP70 gene amplified from 102 animals representing seven cattle populations (Bali, Belgian Blue x Peranakan Ongole [PO] cross, Galekan, Jabres, Madura, PO, and Rambon) were sequenced by DNA sequencing method.

Results: Fourteen single-nucleotide polymorphisms (SNPs), generally found at a low frequency, were detected. Among these SNPs, only $1117 \mathrm{G}>\mathrm{A}, 1125 \mathrm{~A}>\mathrm{C}$, and $1204 \mathrm{~T}>\mathrm{C}$ were polymorphic in all the analyzed breeds. A Chi-square test showed that the majority of the loci were in Hardy-Weinberg equilibrium $(\mathrm{p}>0.05)$. Varying levels of observed $(0.050-0.571)$ and expected heterozygosity (0.049-0.500) were noted. The polymorphism information content values $(0.048-0.375)$ indicated that the SNPs in the HSP70 gene showed low-to-moderate polymorphism in the studied populations. Thirtysix haplotypes were defined according to the identified SNPs, of which haplotype Hap5 (CGACGAGAGTGTCC) and Hap4 (CGACGAGAGTGCCC) were generally dominant in the studied samples. The phylogenetic tree showed a close relationship between Bali and Rambon cattle and between Galekan and Jabres cattle, while the Belgian Blue x PO crossbred cattle were farther apart.
\end{abstract}

Conclusion: The polymorphisms in the 5' UTR of the HSP70 gene identified in this study should be further investigated in a larger population to unravel the association between the SNPs and thermotolerance in Indonesian local cattle populations.

Keywords: cattle, heat shock protein, heat stress, polymorphism, thermotolerance.

\section{Introduction}

Cattle farming plays a significant economic and social role for rural households in developing countries like Indonesia. Many local cattle breeds are reared by livestock farmers, especially in the rural areas with low-input farming systems, contributing approximately $90 \%$ of total cattle production in Indonesia [1]. However, cattle often suffer from various thermal stresses in tropical regions like Indonesia, such as heat stress. Heat stress is a significant threat to the viability and sustainability of cattle production and has been associated with reducing productive and reproductive performances, leading to economic losses. It is important to exploit the genetic variation underlying thermotolerance traits to reduce heat stress on cattle production.

Copyright: Prihandini, et al. Open Access. This article is distributed under the terms of the Creative Commons Attribution 4.0 International License (http://creativecommons.org/licenses/ by/4.0/), which permits unrestricted use, distribution, and reproduction in any medium, provided you give appropriate credit to the original author(s) and the source, provide a link to the Creative Commons license, and indicate if changes were made. The Creative Commons Public Domain Dedication waiver (http:// creativecommons.org/publicdomain/zero/1.0/) applies to the data made available in this article, unless otherwise stated.
Certain genes are beneficial in heat stress tolerance. These genes include heat shock proteins (HSPs), a group of proteins that play a major role in providing thermotolerance in cells and protecting cells against apoptosis during injury and cellular stress [2]. HSPs are released in cells in response to several environmental and oxidative stresses [3]. Most HSPs functionally act as molecular chaperones by selectively recognizing and binding non-native proteins, preventing irreversible aggregation under physiological and stress conditions [4]. The HSPs family consists of HSP110, HSP100, HSP90, HSP70, HSP60, HSP40, HSP10, and small HSP. Among them, HSP70 is the most conserved, sensitive, and abundant gene associated with stress [5,6]. HSP70 is produced by the HSP70 gene, characterized by a single exon. The open reading frame of this gene is approximately 1926, and its protein consists of 641 amino acids. Heat shock genes are activated by stressful stimuli, forming HSPs [7].

Abundant genetic variations in the HSP70 gene sequences have been reported in some livestock animals, such as in cattle [8-11], goats [12-14], and chickens [15]. HSP70 gene polymorphisms are genetically 
associated with milk production traits in Frieswal crossbred cattle [8], blood biochemical parameters in Holstein cattle [16], and heat thermotolerance (HTC) in Tharparkar cattle [9]. Studies reported abundant polymorphisms in the 5 , untranslated region of the HSP70 in cattle $[10,11,17]$. A single-nucleotide polymorphism (SNP) at $1128 \mathrm{G}>\mathrm{T}$ in the 5' UTR of the HSP70 gene is associated with an increased ability of peripheral blood mononuclear cells (PBMCs) to respond to heat shock [18]. At present, there is a paucity of literature on the identification of the HSP70 gene polymorphisms in Indonesian cattle [11]. Good knowledge of the genetic polymorphisms in certain genes will be helpful in determining the SNPs responsible for important economic traits [19,20].

Therefore, this study aimed to identify the genetic polymorphisms of the 5' UTR of the HSP70 gene in various cattle populations in Indonesia, which may be helpful in the genetic improvement of the cattle for heat tolerance traits.

\section{Materials and Methods}

\section{Ethical approval}

The experimental procedures were approved by the Institutional Animal Care and Use Committee of the Indonesian Agency for Agricultural Research and Development (Balitbangtan/Lolitsapi/Rm/09/2020).

\section{Study period and location}

The study was conducted from January to December 2020. All the breeds analyzed were obtained from the Beef Cattle Research Institute (BCRI) of Grati, East Java. In addition, the Galekan, Rambon, and Jabres cattle were also collected from Trenggalek of East Java Province, Banyuwangi of East Java Province, and Brebes of Central Java Province, respectively. The samples were processed at the Laboratory of Animal Molecular Genetics, BCRI.

\section{Animals and sampling}

A total of 102 animals from several cattle populations raised in Indonesia were used. Breeds analyzed included Bali ( $\mathrm{n}=16)$, PO $(\mathrm{n}=20)$, Belgian Blue x PO cross (BBPO; $n=7)$, Galekan $(n=8)$, Jabres $(n=18)$, Madura ( $\mathrm{n}=17)$, and Rambon $(\mathrm{n}=16)$. Blood samples taken from the jugular vein were collected in $3 \mathrm{~mL}$ tubes containing EDTA as an anticoagulant and stored at $4^{\circ} \mathrm{C}$ before being analyzed.

\section{DNA extraction and polymerase chain reaction (PCR) amplification}

Genomic DNA was extracted from the blood samples using a gSYNCTM DNA extraction kit (Geneaid, New Taipei City, Taiwan), following the manufacturer's instructions. A specific pair of primers, HSP70_F, 5'-GTCGCCAGGAAACCAGAGAC-3' and HSP70_R, 5'- GGAACACCCCTACGCAGGAG-3' [21], was used to amplify the $551 \mathrm{bp}$ of the bovine HSP70 gene (GenBank Accession No. M98823). The PCR reaction, which consisted of $2 \mu \mathrm{L}$ template DNA (10-100 ng), $0.5 \mu \mathrm{L}$ of each primer $(0.25 \mu \mathrm{M}), 12.5 \mu \mathrm{L}$ PCR kit diluent (2x My Taq HS Red Mix gSYNCTMPCR Kit-BiolineLondon), and $9.5 \mu \mathrm{L} \mathrm{ddH} 2 \mathrm{O}$ for a total volume of $25 \mu \mathrm{L}$, was conducted using SensoQuest (Germany). The thermal cycle profile included an initial denaturation at $95^{\circ} \mathrm{C}$ for $5 \mathrm{~min}$, followed by 35 cycles of $94^{\circ} \mathrm{C}$ for $45 \mathrm{~s}, 60^{\circ} \mathrm{C}$ for $45 \mathrm{~s}$, and $72^{\circ} \mathrm{C}$ for $60 \mathrm{~s}$, with a final extension step at $72^{\circ} \mathrm{C}$ for $5 \mathrm{~min}$. The PCR products were confirmed by electrophoresis on a $1.5 \%$ agarose gel before sequencing using an ABI 3730xl genetic analyzer (Applied Biosystems, Foster City, CA, USA).

\section{Statistical analysis}

The HSP70 gene sequencing results were arranged, edited, and aligned using BioEdit software [22]. Allele and genotype frequencies, observed and expected heterozygosity, and Chi-square $\left(\chi^{2}\right)$ tests were determined using POPGENE 1.32 software [23]. The polymorphism information content (PIC) was also calculated. Haplotype combination for the fourteen polymorphic sites was estimated using DnaSP version 6.12.01 software [24]. A neighbor-joining (NJ) phylogenetic tree was constructed using MEGA version 5.0 [25].

\section{Results}

\section{Polymorphisms and genetic diversity}

A $551 \mathrm{bp}$ fragment of the 5' UTR of the bovine HSP70 gene was amplified and sequenced for 102 animals from seven cattle populations in Indonesia. Consequently, 14 SNPs, namely, nt $1036 \mathrm{C}>\mathrm{T}$, $1045 \mathrm{G}>\mathrm{A}, \quad 1058 \mathrm{~A}>\mathrm{G}, \quad 1069 \mathrm{C}>\mathrm{T}, \quad 1076 \mathrm{G}>\mathrm{A}$, $1096 \mathrm{~A}>\mathrm{G}, 1117 \mathrm{G}>\mathrm{A}, 1125 \mathrm{~A}>\mathrm{C}, 1128 \mathrm{G}>\mathrm{T}, 1134 \mathrm{~T}>\mathrm{C}$, $1164 \mathrm{G}>\mathrm{T}, 1204 \mathrm{~T}>\mathrm{C}, 1255 \mathrm{C}>\mathrm{T}$, and $1262 \mathrm{C}>\mathrm{T}$, were identified across the pooled samples (Supplementary data can be available from the corresponding author). In general, the SNPs found in this study were at a low frequency. Only three loci, namely, nt $1117 \mathrm{G}>\mathrm{A}$, $1125 \mathrm{~A}>\mathrm{C}$, and $1204 \mathrm{~T}>\mathrm{C}$, were polymorphic in all the analyzed breeds.

The Chi-square $\left(\chi^{2}\right)$ tests showed that the frequencies of the genotypes were in agreement with the Hardy-Weinberg equilibrium ( $p>0.05$ ), except for $n t$ $1096 \mathrm{~A}>\mathrm{G}$ in Bali cattle, nt $1128 \mathrm{G}>\mathrm{T}$ in BBPO cattle, nt $1117 \mathrm{G}>\mathrm{A}$ in Jabres cattle, nt $1045 \mathrm{G}>\mathrm{A}, 1096 \mathrm{~A}>\mathrm{G}$, $1117 \mathrm{G}>\mathrm{A}$, and $1125 \mathrm{~A}>\mathrm{C}$ in Madura cattle, nt $1076 \mathrm{G}>\mathrm{A}$ in PO cattle, and $1262 \mathrm{C}>\mathrm{T}$ in Rambon cattle. The observed and expected heterozygosity varied from 0.050 to 0.571 and from 0.049 to 0.500 , respectively. To obtain information regarding the 14 identified SNPs, the PIC value for each locus was estimated as per the classification: PIC value $<0.25$, low polymorphism; $0.25 \leq$ PIC value $\leq 0.5$, intermediate polymorphism; and PIC value $>0.5$, high polymorphism [26]. The PIC values ranged from 0.048 to 0.375 , indicating that the SNPs in the HSP70 gene exhibited low-to-moderate polymorphism in the studied populations.

\section{Haplotype and phylogenetic analysis}

Based on the 14 SNPs, 36 haplotypes were identified in the experimental samples (Supplementary 
data can be available from the corresponding author). The two most common haplotypes in all breeds were Hap5 (CGACGAGAGTGTCC) and Hap4 (CGACGAGAGTGCCC), with frequencies of 0.25 and 0.22 , respectively. The frequencies of the remaining haplotypes ranged from 0.01 to 0.05 . Nei's genetic distance ranged from 0.138 (between Galekan and Bali cattle) to 0.382 (between Jabres and BBPO cattle) (Table-1). As shown in Figure 1, the phylogenetic tree of the seven cattle populations constructed from the matrix genetic distance indicated that Bali and Rambon cattle were closer, followed by Galekan, Jabres, Madura, and PO cattle, while BBPO crossbred cattle were farther apart.

\section{Discussion}

Heat stress has become a significant issue in climate change because it directly impacts the adaptability and survivability of farm animals to thermal assault. The HSP genes such as HSP70 and HSP90 are members of HSPs subfamily (molecular chaperone families) known to be highly expressed under stressful environmental and physiological conditions [27]. This study analyzed the polymorphisms of the 5' UTR of the HSP70 gene in the seven cattle populations in Indonesia. A total of 14 SNPs were found after direct sequencing and alignment of all the sequences from 102 samples. These SNPs can be further compared with those reported in published studies.

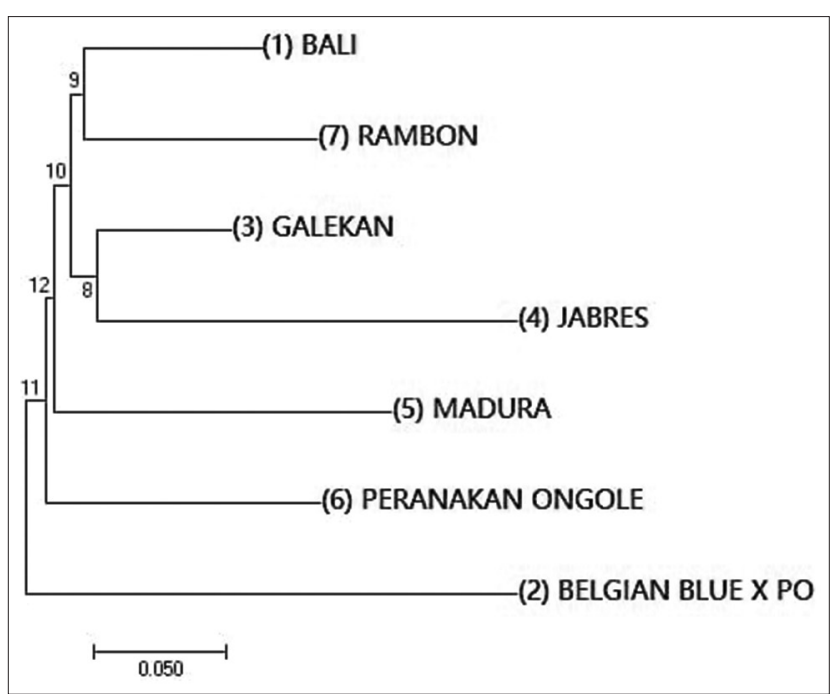

Figure-1: Phylogenetic relationship of the HSP7O gene sequences among Indonesian cattle populations.
In mammals like cattle, the HSP70 gene was extensively studied. All the SNPs found in this study have been reported previously in Pasundan cattle, except for $n t 1076 \mathrm{G}>\mathrm{A}$ [11]. This SNP, however, was found in South African Nguni crossbred cattle [10] and in this study. Interestingly, SNP at nt $1164 \mathrm{G}>\mathrm{T}$ identified in this study was also found in Pasundan cattle from Indonesia [11], but this SNP was absent in South African Nguni crossbred cattle [10]. Öner et al. [17] sequenced the 5' UTR of the HSP70 gene in native Turkish and Holstein Friesian cattle and found an abundance of polymorphisms. Among the 14 SNPs identified in this study, only SNPs at nt $1036 \mathrm{C}>\mathrm{T}$, nt $1069 \mathrm{C}>\mathrm{T}$, and nt $1262 \mathrm{C}>\mathrm{T}$ were absent in Turkish and Holstein Friesian cattle [17]. Similar to the results of this study, the majority of SNPs found in the 5' UTR of the HSP70 gene is at low frequency $[11,17]$. Several SNPs previously found in the HSP70 gene, including nt $1045 \mathrm{G}>\mathrm{A}, 1117 \mathrm{G}>\mathrm{A}, 1125 \mathrm{~A}>\mathrm{C}$, $1128 \mathrm{G}>\mathrm{T}, 1134 \mathrm{~T}>\mathrm{C}$, and $1204 \mathrm{~T}>\mathrm{C}[8,17,18]$, were also observed in Indonesian cattle. It is noteworthy that the 5' UTR of the HSP70 gene contains considerable polymorphisms.

Some previous studies showed the relationship between polymorphisms in the HSP70 gene and particular traits of interest. For instance, Bhat et al. [9] found a significant association between HSP70 gene polymorphism and HTC in Tharparkar cattle, while Hu et al. [28] reported that two SNPs (SNP-42- and SNP $-205^{+}$) are causative polymorphisms involved in the modulation of HSP70 promoter activity and might contribute to the association between the HSP70 gene and triiodothyronine and thyroxine levels in Sanhe cattle. Among many SNPs found in the 5' UTR of the HSP70 gene, SNP at nt $1128 \mathrm{G}>\mathrm{T}$ is associated with an increased ability of PBMC to respond to heat shock in terms of gene expression and synthesis of HSP70 and cell viability [18]. This SNP was also found in this study; thus, it is necessary to investigate its association with HTC in Indonesian cattle. The SNPs at nt $1045 \mathrm{G}>\mathrm{A}, 1134 \mathrm{~T}>\mathrm{C}$, and $1204 \mathrm{~T}>\mathrm{C}$, which were identified in this study, have been reported to be associated with the serum concentration of T3 and IGF-I and body condition $[29,30]$. Among these SNPs, only nt $1204 \mathrm{~T}>\mathrm{C}$ was observed in all the breeds investigated in this study, while the nt $1045 \mathrm{G}>\mathrm{A}$ and $1134 \mathrm{~T}>\mathrm{C}$ were identified in all the breeds, except in Jabres cattle (both SNPs) and PO cattle (nt 1134T $>$ C). Therefore,

Table-1: Pairwise genetic distance between the seven cattle populations based on the HSP70 SNPS.

\begin{tabular}{|c|c|c|c|c|c|c|c|}
\hline Population & Bali & BBPO & Galekan & Jabres & Madura & PO & Rambon \\
\hline \multicolumn{8}{|l|}{ Bali } \\
\hline BBPO & 0.257 & & & & & & \\
\hline Galekan & 0.138 & 0.266 & & & & & \\
\hline Jabres & 0.243 & 0.382 & 0.208 & & & & \\
\hline Madura & 0.207 & 0.321 & 0.193 & 0.294 & & & \\
\hline PO & 0.192 & 0.295 & 0.164 & 0.276 & 0.233 & & \\
\hline Rambon & 0.154 & 0.294 & 0.151 & 0.253 & 0.228 & 0.206 & \\
\hline
\end{tabular}

$\mathrm{PO}=$ Peranakan Ongole cattle, BBPO=Belgian Blue $\times$ PO cattle 
the SNPs identified in this study may be helpful in the association analysis with certain traits of interest, especially HTC in cattle.

All of the SNPs found in this study were used to define the haplotype of the HSP70 gene in Indonesian cattle. Thirty-six haplotypes were identified, of which haplotypes Hap4 and Hap5 represent the most frequent haplotypes of the HSP70 gene in the studied populations. Based on the matrix genetic distance, a NJ tree was constructed to show the phylogenetic relationship of the studied populations (Figure-1). The NJ tree indicated that Bali and Rambon cattle were genetically close to Galekan and Jabres, followed by Madura and PO cattle, while BBPO crossbred cattle was farther apart. In general, the findings indicated that all the Indonesian cattle studied were more closely related, except for the crossbred cattle, which showed a separate cluster from other breeds. The results of this study support the findings of Hartatik et al. [31] who reported a close genetic relationship between Indonesian local cattle and Bali cattle, which is a domesticated descendant of the wild Banteng (Bos javanicus).

\section{Conclusion}

This study demonstrates polymorphisms in the 5' UTRs of the HSP70 gene among the seven cattle populations in Indonesia. The SNPs that occur at a moderate frequency should be further investigated in a larger population to unravel the association between the SNPs and thermotolerance in cattle.

\section{Data Availability statement}

The supplementary data can be available from the corresponding author upon a reasonable request.

\section{Authors' Contributions}

PWP, AA, and ML: Designed the study and collected the samples. AP: Collected samples and performed laboratory analysis. DNHH: Analyzed the data and wrote the manuscript. All authors have read and approved the final manuscript.

\section{Acknowledgments}

This study was supported by grants from the Ministry of Agriculture of the Republic of Indonesia through the Agency of Agricultural Research and Development (SP DIPA-018.09.2.648720/2020).

\section{Competing Interests} interests.

The authors declare that they have no competing

\section{Publisher's Note}

Veterinary World remains neutral with regard to jurisdictional claims in published institutional affiliation

\section{References}

1. Agus, A. and Widi, T.S.M. (2018) Current situation and future prospects for beef cattle production in Indonesia a review. Asian Australas. J. Anim. Sci., 31(7): 976-983.

2. Beere, H.M. and Green, D.R. (2001) Stress management-heat shock protein-70 and the regulation of apoptosis. Trends Cell Biol., 11(1): 6-10.

3. Hecker, J.G. and McGarvey, M. (2011) Heat shock proteins as bio-markers for the rapid detection of brain and spinal cord ischemia: A review and comparison to other methods of detection in thoracic aneurysm repair. Cell Stress Chaperones, 16(2): 119-131.

4. Buchner, J. (1996) Supervising the fold: Functional principles of molecular chaperones. FASEB J., 10(1): 10-19.

5. Kiang, J.G. and Tsokos, G.C. (1998) Heat shock protein $70 \mathrm{kDa}$ : Molecular biology, biochemistry, and physiology. Pharmacol. Ther., 80(2): 183-201.

6. Hassan, F., Nawaz, A., Rehman, M.S., Ali, M.A., Dilshad, S.M.R. and Yang, C. (2019) Prospects of HSP70 as a genetic marker for thermo-tolerance and immuno-modulation in animals under climate change scenario. Anim. Nutr., 5(4): 340-350.

7. Christians, E.S., Zhou, Q., Renard, J. and Benjamin, I.J. (2003) Heat shock proteins in mammalian development. Semin. Cell Dev. Biol., 4(5): 283-290.

8. Deb, R., Sajjanar, B., Singh, U., Kumar, S., Brahmane, M.P., Singh, R., Sengar, G. and Sharma, A. (2013) Promoter variants at AP2 box region of Hsp70.1 affect thermal stress response and milk production traits in Frieswal crossbred cattle. Gene, 532(2): 230-235.

9. Bhat, S., Kumar, P., Kashyap, N., Deshmukh, B., Dige, M.S., Bhushan, B., Chauhan, A., Kumar, A. and Singh, G. (2016) Effect of heat shock protein 70 polymorphism on thermotolerance in Tharparkar cattle. Vet. World, 9(2): 113-117.

10. Mkize, L.S. and Zishiri, O.T. (2020) Novel single nucleotide polymorphisms in the heat shock protein 70.1 gene in South African Nguni crossbred cattle. Trop. Anim. Health Prod., 52(2): 893-901.

11. Said, S. and Putra, W.P.B. (2018) Novel single nucleotide polymorphisms (SNPs) in the 5'UTR of bovine heat shock protein 70 (bHSP70) gene and its association with service per conception $(\mathrm{S} / \mathrm{C})$ of Pasundan cattle. Biodiversitas, 19(5): 1622-1625.

12. Gade, N., Mahapatra, R.K., Sonawane, A., Singh, V.K., Doreswamy, R. and Saini, M. (2010) Molecular characterization of heat shock protein 70-1 gene of goat (Capra hircus). Mol. Biol. Int., 2010: 108429.

13. Nikbin, S., Panandam, J.M., Yaakub, H., Murugaiyah, M. and Sazili, A.Q. (2014) Novel SNPs in heat shock protein 70 gene and their association with sperm quality traits of Boer goats and Boer crosses. Anim. Reprod. Sci., 146(3-4): 176-181.

14. Mohalik, P.K., Sahoo, S.S., Mishra, C., Dash, S.K. and Nayak, G. (2021) Novel polymorphism of HSP70 gene affected caprine physiological vital parameters. Anim. Biotechnol., 32(5): 550-557.

15. Najafi, M., Rouhi, M.A., Mokhtari, R. and Kazemi, H. (2018) Genetic analysis of a novel polymorphism in coding region of HSP70 gene and its association with some productive and reproductive traits in Mazandaran breeder hens. $J$. Genet. Disord. Genet. Med., 2(1): 1-5.

16. Abbas, Z., Hu, L., Fang, H., Sammad, A., Kang, L., Brito, L.F., Xu, Q. and Wang, Y. (2020) Association analysis of polymorphisms in the 5' flanking region of the HSP70 gene with blood biochemical parameters of lactating Holstein cows under heat and cold stress. Animals, 10(11): 2016.

17. Öner, Y., Keskin, A., Üstüner, H., Soysal, D. and Karakaş, V. (2017) Genetic diversity of the 3' and 5' untranslated regions of the HSP70.1 gene between native Turkish and Holstein Friesian cattle breeds. S. Afr. J. Anim. Sci., 47(4): 424-439.

18. Basiricó, L., Morera, P., Primi, V., Lacetera, N., Nardone, A. and Bernabucci, U. (2011) Cellular thermotolerance is associated with heat shock protein 70.1 genetic polymorphisms in Holstein lactating cows. Cell Stress Chaperones, 16(4): 


\section{1-448.}

19. Prihandini, P.W., Primasari, A., Aryogi, A., Efendy, J., Luthfi, M., Pamungkas, D. and Hariyono, D.N.H. (2021) Genetic variation in the first intron and exon of the myostatin gene in several Indonesian cattle populations. Vet. World, 14(5): 1197-1201.

20. Antonius, A., Ginting, S.P., Elieser, S., Tarigan, A., Solehudin, S., Budisatria, I.G.S., Sari, A.P.Z.N.L., Hariyono, D.N.H. and Maharani, D. (2020) The association of single nucleotide polymorphism (SNP) g. $281 \mathrm{G}>\mathrm{A}$ of CAST gene with meat quality of Boerka goat. Iran. J. Appl. Anim. Sci., 10(2): 303-309.

21. Schwerin, M., Sanftleben, H. and Grupe, S. (2003) Genetic predisposition for productive life is associated with functional inactivation of an AP2-binding site in the promoter of the stress protein 70.1-encoding gene in cattle. Arch. Anim. Breed, 46(2): 177-185.

22. Hall, T. (1999) Bioedit: A biological sequence alignment editor and analysis program for windows 95/98/nt. Nucleic Acids Symp. Ser., 41(2): 95-98.

23. Yeh, F.C., Yang, R.C., Boyle, T.B.J., Ye, Z.H. and Mao, J.X. (1997) Popgene, the User Friendly Shareware for Population Genetic Analysis. Molecular Biology and Biotechnology Center, Alberta, Canada.

24. Rozas, J., Ferrer-Mata, A., Sanchez-DelBarrio, J.C., Guirao-Rico, S., Librado, P., Ramos-Onsins, S.E. and Sánchez-Gracia, A. (2017) DnaSP 6: DNA sequence polymorphism analysis of large data sets. Mol. Biol. Evol., 34(12): 3299-3302.

25. Kumar, S., Stecher, G. and Tamura, K. (2016) MEGA7: Molecular evolutionary genetic analysis version 7.0 for bigger datasets. Mol. Biol. Evol., 33(7): 1870-1874.

26. Botstein, D., White, R.L., Skolnick, M. and Davis, R.W. (1980) Construction of a genetic linkage map in man using restriction fragment length polymorphisms. Am. J. Hum. Genet., 32(3): 314-331.

27. Onasanya, G., Msalya, G., Thiruvenkadan, A., Sreekumar, C., Tirumurugaan, K., Muyideen, S., Decampos, J., Amusan, A., Olowofeso, O., Fafiolu, A., Okpeku, M., Yakubu, A. and Ikeobi, C. (2020) Evaluation of polymorphisms at heat shock protein 90 gene by high resolution melting assays for potential heat tolerance among Nigerian zebu cattle breeds. Am. J. Anim. Vet. Sci., 15(1): 32-42.

28. Hu, L., Ma, Y., Liu, L., Kang, L., Brito, L.F., Wang, D., Wu, H., Liu, A., Wang, Y. and Xu, Q. (2019) Detection of functional polymorphisms in the hsp70 gene and association with cold stress response in Inner-Mongolia Sanhe cattle. Cell Stress Chaperones, 24(2): 409-418.

29. Banks, A., Looper, M.L., Reiter, S., Starkey, L., Flores, R., Hallford, D. and Rosenkrans, C. Jr. (2007) Identification of single nucleotide polymorphisms within the promoter region of the bovine heat shock protein 70 gene and associations with pregnancy. J. Anim. Sci., 85(Suppl 2): 12-13.

30. Rosenkrans, C. Jr., Banks, A., Reiter, S. and Looper, M. (2010) Calving traits of crossbred Brahman cows are associated with heat shock protein 70 genetic polymorphisms. Anim. Reprod. Sci., 119(3-4): 178-182.

31. Hartatik, T., Hariyono, D.N.H. and Adinata, Y. (2019) Genetic diversity and phylogenetic analysis of two Indonesian local cattle breeds based on cytochrome $b$ gene sequences. Biodiversitas, 20(1): 17-22.

\section{$* * * * * * * *$}

